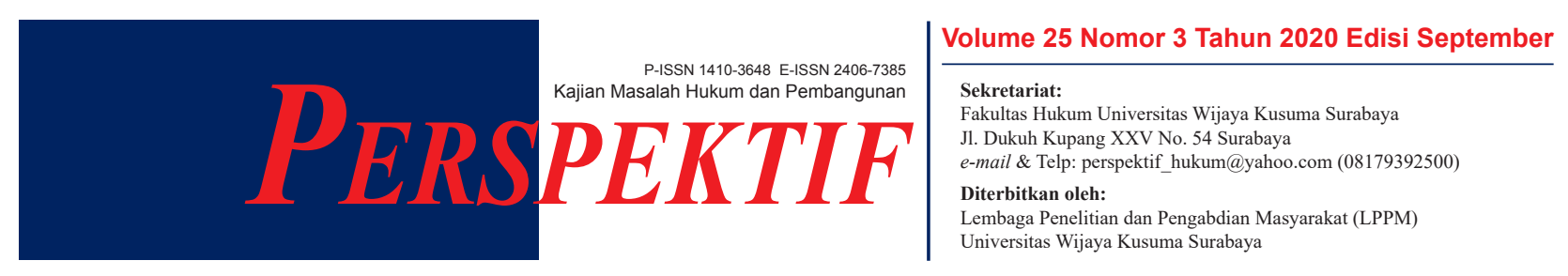

\title{
IMPLEMENTASI HUKUM WARIS TIONGHOA DALAM MASYARAKAT PLURAL DI KOTA BANJARMASIN
}

\author{
Firqah Annajiyah Mansyuroh \\ UIN Antasari Banjarmasin \\ e-mail: firqahannajiyahmansyuroh@gmail.com
}

\begin{abstract}
ABSTRAK
Permasalahan yang akan diteliti adalah bagaimana pelaksanaan pembagian harta warisan pada masyarakat Tionghoa di Banjarmasin serta bagaimana kedudukan hak waris anak beragama Islam dengan orangtua beda agama. Metode yang digunakan dalam penelitian hukum empiris ini adalah sociolegal research dalam ranah legal pluralism yang didukung dengan pengumpulan bahan hukum melalui wawancara. Heterogenitas keyakinan yang ada pada masyarakat etnis Tionghoa Banjarmasin telah mempengaruhi pilihan hukum waris. Adanya perubahan hukum waris di kalangan keluarga Tionghoa di Banjarmasin telah bergeser dari hukum adat yang hanya memberikan warisan kepada anak laki-laki, kini berubah menjadi menerapkan aturan hukum seperti pada hukum waris Perdata dimana perempuan juga mendapatkan hak waris. Pergeseran juga terjadi pada warisan yang diberikan kepada anggota keluarga penganut agama dan kepercayaan selain Tionghoa. Keluarga Tionghoa Banjarmasin yang beragama Islam kini menerapkan sistem waris sesuai dengan hukum Islam, begitu pula terhadap keluarga etnis Tionghoa yang tidak mempermasalahkan perpindahan agama tetap memberikan hak waris. Hal ini berbeda dengan keluarga Tionghoa yang masih berpegang teguh pada tradisi cenderung menghapus hak ahli waris jika berbeda keyakinan. Perbedaan pilihan tersebut disebabkan oleh asimilasi, toleransi kepada prilaku menyimpang, pendidikan, penduduk heterogen, serta pluralitas hukum yang menyebabkan perbedaan implementasi hukum waris tersebut.
\end{abstract}

Kata Kunci: Pewarisan; Tionghoa; Pluralitas; Hukum Waris

\section{ABSTRACT}

The problem to be studied are how the distribution of inheritance in Banjarmasin Chinese ethnic families and how the position of the inheritance rights of Moslem children with interfaith parents. The method used in this empirical legal research is socio-legal research in legal pluralism which is supported by collecting legal materials through interviews. The heterogeneity of beliefs that exist in Banjarmasin Chinese ethnic community has influenced their choice of inheritance law. The change in inheritance law among Chinese families in Banjarmasin has shifted from the customary law which only gives inheritance to boys, now changed to apply inheritance law in civil law where women also get rights. The shift also occurred in the inheritance given to family members adhering to religions and beliefs. Banjarmasin Chinese families who are Moslem are now implementing an inheritance system in accordance with Islamic law, as well as Chinese families who do not mind with religious conversion. This is different from Chinese families which still adhere to tradition, who tend to abolish the rights of the heirs. It has caused by assimilation, tolerance for deviant behavior, education, heterogeneous population, and plurality of laws that cause differences in the implementation of inheritance law.

Keywords: Inheritance; Tionghoa; Pluralistic; Inheritance law 


\section{PENDAHULUAN}

Negara Kesatuan Republik Indonesia merupakan negara yang mempunyai berbagai suku bangsa, bahasa, agama dan adat istiadat yang sangat beragam, termasuk hukum adat yang melekat pada masyarakatnya. Dari beragam suku bangsa yang ada di Indonesia, Etnis Tionghoa adalah salah satunya. Ir. Soekarno, pendiri sekaligus Presiden pertama Negara Republik Indonesia, menyatakan bahwa etnis Tionghoa yang lahir dan berada di wilayah Hindia Belanda sebagai bagian yang koheren dari bangsa Indonesia. ${ }^{1}$ Meski memiliki hukum adatnya sendiri, berdasarkan Pasal 131 Indische Staatsregeling (IS) masyarakat Tionghoa murupakan salah satu golongan penduduk yang berlaku Hukum Perdata Indonesia. Tetapi didalam implimentasinya bertentangan dengan hukum adat yang ada pada masyarakat Tionghoa tersebut. Secara aturan mereka harus tunduk pada Kitab Undang-Undang Hukum Perdata, akan tetapi kebanyakan dari masyarakat Tionghoa Indonesia didalam hal pembagian warisan mereka masih menggunakan hukum adat Tionghoa. Hal ini dikarenakan perbedaan yang signifikan antara nilainilai budaya, kepercayaan, dan pola kekerabatan orang Tionghoa dengan golongan Eropa yang membuat Kitab Undang-Undang Hukum Perdata. ${ }^{2}$

Mengenai perkara pembagian harta warisan, Etnis Tionghoa menjalankannya berdasarkan tipe Patrilineal Descent atau Adnatic, yaitu anak laki-laki adalah pewaris yang memiliki hak penuh atas harta yang ditinggalkan oleh orangtuanya. Anak laki-laki menjadi prioritas dalam keluarga dibandingkan anak perempuan. Hal ini disebabkan berlakunya sistem patrilineal dalam konsep hukum adat Tionghoa yang mengutamakan laki-laki sebagai ahli waris dimana anak laki-laki berfungsi sebagai orang yang bertanggung jawab atas kelangsungan hidup keluarga besar. Sedangkan anak perempuan yang sudah menikah maka ia menjadi bagian dari keluarga besar suaminya. ${ }^{3}$

\footnotetext{
${ }^{1}$ Beatrix Benni. "Pewarisan Pada Etnis Tionghoa Dalam Pluralitas Hukum Waris Di Indonesia." Masalah-Masalah Hukum. Vol. 44 No. 1 Januari 2015: 1-10.

2 Isti Sulistyorini. "Pergeseran Hukum Pewarisan Masyarakat Tionghoa Di Kota Pekalongan.” Jurisprudence. Vo. 1 No. 2 Juli 2013: 367-376.

${ }^{3}$ Fokky Fuad and Ratrie. "Kedudukan dan Hak Waris Bagi Perempuan Dalam Budaya Hukum Confucius.” Lex Jurnalica. Vol. 4 No. 3 Agustus 2007: 116-131.
}

Tetapi tidak dapat dipungkiri bahwa setiap masyarakat, pada kurun waktu dan lokal ruangnya masing-masing, akan bertransformasi atau mengalami perubahan seiring dengan perkembangan masyarakat dan zaman. Kita dapat melihat transformasi tersebut pada pola-pola perilaku manusia yang cenderung berubah. Perubahan tersebut dapat berupa transisi pada nilai-nilai, peralihan norma-norma, modifikasi pola-pola perilaku dan lainnya. Demikian juga dalam sistem pewarisan yang dipakai oleh masyarakat Tionghoa Banjarmasin.

Banjarmasin termasuk kategori kota besar yang termasuk wilayah urban dengan sebagian besar penduduk kota Banjarmasin berasal dari etnis Banjar yang beragama Islam. Banjarmasin termasuk kota yang plural, masyarakatnya bersedia menerima keberagaman (pluralitas) untuk hidup secara toleran pada tatanan masyarakat yang memiliki keanekaan suku, gologan, agama, adat, hingga prinsip-prinsip dalam hidup.

Tionghoa adalah etnis ke empat terbanyak di Banjarmasin setelah Jawa dan Madura. ${ }^{4}$ Etnis Tionghoa sangat beragam dalam menganut keyakinan beragama. Dari mereka ada yang menjadi penganut Khonghucu, Taoisme, Buddhisme, Protestan, Katolik, dan tidak jarang pula ada yang menganut Islam. Bahkan banyak dari mereka yang akhirnya memiliki perbedaan agama antara orangtua dan anak, baik karena keputusan pindah agama secara pribadi maupun karena terjadi pernikahan dengan etnis asli suku Banjar yang beragama Islam.

Perkembangan etnis Tionghoa di Banjarmasin akan mempengaruhi pemakaian hukum waris yang akan diberlakukan bagi kelompok ini. Beberapa pihak boleh jadi tetap memakai hukum waris adat sesuai dengan ajaran Confucius (patrilineal), atau menggunakan hukum waris Perdata sesuai dengan undang-undang, atau mereka menetapkan sesuai dengan kesepakatan musyawarah bersama keluarga. Hal ini bisa saja berjalan salah satunya karena heterogenitas agama yang ada pada etnis Tionghoa Banjarmasin. Misalnya saja bagi yang memiliki

4 Badan Perencanaan Pembangunan Daerah Kota Banjarmasin dan Badan Pusat Statistik Kota Banjarmasin. (2013). "Profil dan Analisis Hasil Sensus Penduduk 2010 dan Proyeksi Penduduk 2010-2020 Kota Banjarmasin". https://banjarmasinkota.bps.go.id/subject/12/kependudukan. html\#subjekViewTab3. 
agama Islam syarat agar bisa mendapatkan warisan dalam hukum Islam harus beragama yang sama. Hal ini sebagaimana disampaikan oleh Rasulullah Saw dalam hadis riwayat Bukhari: "Orang muslim tidak bisa mewarisi orang kafir (begitu juga sebaliknya) orang kafir tidak bisa mewarisi orang muslim". ${ }^{5}$

\section{PERUMUSAN MASALAH}

Berlandaskan latar belakang yang telah diuraikan di atas, maka yang menjadi permasalahan yang ingin dijawab dalam penelitian ini adalah: Bagaimana implementasi pembagian harta warisan pada masyarakat etnis Tionghoa di Kota Banjarmasin dan Bagaimana kedudukan hak waris anak beragama Islam dengan orangtua beda agama pada masyarakat Tionghoa Banjarmasin.

\section{METODE PENELITIAN}

Metode penelitian yang dipergunakan dalam penelitian ini adalah metode penelitian empiris menggunakan socio-legal research atau pendekatan non-doktrinal dalam ranah legal pluralism. Pendekatan ini dilakukan untuk menginterpretasikan hukum dalam konteks masyarakat dan juga dari aspek natural law (moral ethic atau adat dan religion atau agama) dalam bingkai the law-society framework. ${ }^{6}$

Guna menjawab pertanyaan dari penelitian ini digunakan metode pengumpulan bahan hukum dengan metode wawancara untuk bahan hukum primer yang dilakukan pada informan dengan etnis Tionghoa pada masyarakat plural di Kota Banjarmasin. Informan ditentukan secara snowball (chain-referral sampling) sesuai dengan kebutuhan dari penelitian ini. Penelitian ini juga dilengkapi dengan library research tentang hukum-hukum dan konsep-konsep yang mendukung ulasan dari permasalahan yang telah diajukan. Pemikiran dari para ahli di bidang hukum dan agama juga akan dijadikan rujukan untuk mendukung data empirik

\footnotetext{
${ }^{5}$ Muhammad bin Ismail Al Bukhari. Shahih Bukhari (Beirut: Dar Ibn Katsir, n.d.). Hadis no. 4282-4283, 6267; Muslim bin al Hajjaj bin Muslim bin Kausyaz al-Qusyairi An-Naisaburi, Shahih Muslim, ed. Dede Ishaq Munawar (Jakarta: Pustaka As-Sunnah, 2010). Hadis No. 1614; Abu Daud Sulaiman bin Al-Asy'atsi AlSijistaanii, Sunan Abu Daud (Makkah: International Ideas Home, 1999). Hadis No. 2909; Muhammad bin Isa At-Tirmidzi, Sunan Tirmidzi (Riyadh: Maktabatu Al Ma'arif, n.d.). Hadis No. 2107.

${ }^{6}$ Suteki and Galang Taufani. (2018). Metodologi Penelitian Hukum (Filsafat, Teori dan Praktik). Depok: Raja Grafindo Persada, h. 305-306.
}

yang diperoleh. Hasil akhir dari penelitian akan disajikan dengan metode analisis deskriptif.

\section{KERANGKA TEORI}

\section{a. Teori Legal Pluralisme}

Secara substansif pluralisme hukum lazim diinterpretasikan sebagai suatu keadaan di mana dua tau lebih sistem hukum bekerja secara bersamasama dalam suatu bagian kehidupan sosial yang sama, atau untuk menjelaskan kehadiran adanya dua atau lebih sistem penyelenggaraan sosial dalam satu aspek aktivitas sosial. Maka dapat dikatakan bahwa ada afinitas atau keterikatan erat antara state dengan hukum positifnya, society dengan adatnya dan natural law dengan agamanya. ${ }^{7}$

Werner Menski mengambil kesimpulan ini tatkala ia sedang melakukan observasi tentang perbandingan hukum antara negara-negara di Asia dan Afrika. Menurutnya bangsa-bangsa di Asia dan Afrika adalah bangsa yang sangat dikuasai oleh adat, moral, agama, etika dalam tata cara berhukumnya. Menurutnya hal ini terjadi karena terciptanya hukum negara-negara yang ada pada dua benua ini bersumber dari dua unsur fundamental yaitu adat dan di samping materi hukum dari Eropa. Legal Pluralisme merupakan integrasi transenden untuk menafsirkan dan menegakkan hukum dalam masyarakat yang beraneka ragam (plural). ${ }^{8}$

b. Teori Law as a Tool Social Engineering

Roscoe Pound mengatakan bahwa fungsi utama hukum adalah untuk memelihara kebutuhan yang ada dalam masyarakat yang bukan merupakan hal absolut tetapi selalu bertransformasi sesuai perkembangan yang ada pada masyarakat. Dalam hal ini hukum diartikan sebagai instrumen yang ditujukan untuk mengoreksi tingkah laku anggota masyarakat, sesuai dengan sasaran yang telah ditetapkan sebelumnya. Hukum adalah agent of change yang merupakan pemrakarsa yang menjadi andalan bagi masyarakat dan membujuk masyarakat dengan pola yang telah dirancang terlebih dahulu. ${ }^{9}$

c. Teori Living Law

Menurut Erlich munculnya hukum hanyalah sebagai wujud dari naturalisme. Semua fenomena yang ada di dunia termasuk juga hukum diteliti

\footnotetext{
${ }^{7}$ ibid., h. 37-39.

8 ibid., h. 39.

${ }^{9}$ Benni. op.cit., h. 3.
} 
seperti benda-benda alam, dan hubungan antara fenomena-fenomena hukum itu ditafsirkan sebagai hal yang bersifat alamiah juga. Oleh karena itu hukum merupakan kenyataan, atau dengan kata lain normanorma hukum yang ada adalah berasal dari kenyataan dalam masyarakat. Erlich kemudian mengikhtisarkan mengenai hukum yang baik. Menurutnya hukum yang baik adalah hukum yang dasar penyusunannya berpangkal atau berkesesuaian dengan kenyataan hukum masyarakat. ${ }^{10}$

\section{PEMBAHASAN}

\section{Etnis Tionghoa di Banjarmasin}

Kota Banjarmasin merupakan ibu kota Provinsi Kalimantan Selatan yang memiliki julukan Kota Seribu Sungai. Mayoritas penduduk kota Banjarmasin berasal dari etnis Banjar yakni sebanyak 79,26\% dari total penduduk. Urang Banjar menumbuhkan strata budaya, strata sosial dan objek budaya yang berkaitan dengan religi, melalui berbagai macam teknik adaptasi, akulturasi, dan asimilasi. Maka akan dapat terlihat jelas terjadinya asimilasi dari segi aspek-aspek budaya di Banjarmasin. Walaupun seperti itu, ajaran atau impresi Islam jauh lebih menonjol dalam kehidupan budaya Banjar, lebihlebih mengenai ajaran-ajaran yang bersinggungan dengan ketuhanan atau aqidah, meskipun dalam perihal aktivitas sehari-hari masih ada komponen dari budaya asal yakni Hindu dan Buddha. ${ }^{11}$

Agama yang ada di Banjarmasin termasuk sangat beragam. Pada tahun 2018 tercatat penduduk yang beragama Islam sebanyak 879.775 jiwa, Protestan 17.429 jiwa, Katolik 14.338 jiwa, Hindu 5.436 jiwa, Budha 6.367 jiwa dan lainnya sebanyak 426 jiwa. ${ }^{12}$ Dengan adanya masyarakat yang majemuk (plural) maka tidak jarang terjadi perbedaan agama yang dianut pada keluarga etnis Tionghoa di Kota Banjarmasin. ${ }^{13}$ Ini menjadikan masyarakat Tionghoa

\footnotetext{
${ }^{10}$ Suteki and Taufani. op.cit., h. 96-97.

${ }^{11}$ Kongres Kebudayaan Indonesia. (2018). "Profil Budaya Kota Banjarmasin.” Kongres Kebudayaan Indonesia. http:// kongres.kebudayaan.id/kota-banjarmasin/.

${ }^{12}$ Badan Pusat Statistik Kota Banjarmasin. (2019). "Kota Banjarmasin Dalam Angka". https://banjarmasinkota.bps.go.id/ publication/2019/08/16/aa133421b5424804385f0b58/kotabanjarmasin-dalam-angka-2019.html, h. 165.

${ }^{13}$ Muhammad Sidik. (2018). Hubungan Antar Penganut Agama Dalam Keluarga (Studi Kasus Etnis Tionghoa Di Banjarmasin). Banjarmasin: Universitas Islam Negeri Antasari, h. 11 .
}

di Banjarmasin sebagai sebuah masyarakat yang majemuk, plural, dan multikultural, serta tidak homogen.

Dalam Kitab Hikayat Banjar dituturkan bahwa orang Tionghoa sudah berlabuh ke Kalimantan Selatan pada abad XIV. Kronik Sejarah Cina pada masa Dinasti Ming mendokumentasikan lawatan saudagar Tionghoa pada masa Sultan Hidayatullah. Penyebutan "Urang Cina" untuk mereka yang beretnis Tionghoa sudah populer dipakai di Kalimantan dan hal tersebut bukanlah penamaan yang memiliki siratan negatif, tetapi semata merupakan penamaan untuk menunjukkan identitas etnik. ${ }^{14}$

Namun sebenarnya jauh sebelum itu hubungan antara Banjarmasin-China sudah lama terjalin. Berdasarkan berbagai literatur sejarah, etnis Banjar dikatakan bermula dari leluhur atau penghuni pendahulu pulau Kalimantan adalah mereka yang beretnis Tionghoa yang datang dari daerah Yunnan Selatan (Tiongkok) kemudian berimigrasi ke pulau Kalimantan. Sesudah mengalami hubungan dan penggabungan dengan berbagai kesukuan dan kedaerahan, mereka ini kelak menghasilkan suku Dayak dan Banjar sebagai etnis utama orang-orang Kalimantan. ${ }^{15}$

Representasi yang berkorelasi dengan China melekat kuat dalam aktivitas sehari-hari dan budaya masyarakat Banjar. Umpamanya citra dan keyakinan tentang hewan mitos semisal Naga, pintu gerbang naga balimbur, budaya air, ukiran, dan berbagai unsur kebudayaan sehari-hari seperti ritus Selamatan, Sesajen, dan Sajian. Bahkan dikatakan bahwa ada sebagian pemuka China yang tercatat dalam sejarah Banjar. Diceritakan pada periode zaman kerajaan Islam Banjar salah seorang putri orang ternama China yang bergelar Kapten Kodok, yakni Tuan Go Hwat Nio telah diperistri oleh ulama besar Kalimantan, Syekh Muhammad Arsyad Al-Banjari, dan memiliki banyak dinasti rumpun yang kemudian menjadi ulama besar. Ini menunjukan ada kekerabatan yang terpadu antara orang Banjar dan China. ${ }^{16}$ Ini

${ }^{14}$ Roedy Haryo Widjono AMZ. (2019). “Jejak Migrasi Etnis Tionghoa Di Kalimantan.” https://www.akurasi.id/jejakmigrasi-etnis-tionghoa-di-kalimantan/.

15 Kurnia Widiastuti and Anna Oktaviana. (2018). "Bentuk Dan Makna Rumah Tinggal Etnis Tionghoa Di Banjarmasin.” Info Teknik. Vol. 16 No. 2. https://doi.org/10.1017/ CBO9781107415324.004, h. 1689-1699.

${ }^{16}$ ibid., h. 244. 
menunjukkan sejak dahulu masyarakat Banjarmasin adalah masyarakat yang majemuk (plural).

\section{Pewarisan pada Etnis Tionghoa di Banjarmasin}

Sebagaimana ketentuan di dalam Staatsblaad 1917 Nomor 129 bahwa Kitab Undang-Undang Hukum Perdata diberlakukan untuk orang dengan etnis Tionghoa dengan sebagian perihal pengecualian, salah satu yang menjadi landasan berlakunya hukum adat Tionghoa adalah beberapa pengkhususan tersebut. Sehingga secara berdikari pelaksanaan adat Tionghoa menjadi opsi alternatif yang sebenarnya diberlakukan tanpa adanya pembatasan terhadap pemberlakuan kepada masyarakat Tionghoa yang bilamana dengan sengaja memang memilih untuk memakai hukum adat Tionghoa dalam pembagian warisnya.${ }^{17} \mathrm{Hal}$ ini dikarenakan berlakunya pluralisme hukum waris di Indonesia yang memperbolehkan warganya memilih hukum yang diberlakukan sesuai dengan masing-masing golongan penduduk.

Kelanjutan dari waris adat Tionghoa yang berlaku pada masyarakat Tionghoa di Indonesia, khususnya di Banjarmasin berjalan dengan berbagai transformasi. Perubahan-perubahan ini secara khusus sebenarnya perlahan-lahan menyingkirkan praktik kekerabatan patrilineal yang selama ini diikuti sangat erat dalam budaya Tionghoa. Etnis Tionghoa secara hukum adat menganut tipe Patrilineal Descent atau Adnatic, yaitu anak laki-laki menjadi prioritas dalam keluarga dibandingkan anak perempuan. Hal ini disebabkan berlakunya sistem patrilineal dalam konsepsi hukum adat Tionghoa yang mengistimewakan laki-laki sebagai ahli waris dimana anak laki-laki berfungsi sebagai orang yang berkewajiban atas kesinambungan hidup keluarga besar. ${ }^{18}$

Dalam hukum adat Tionghoa pembagian warisan juga memegang tujuan pendistribusian terhadap harta-harta pusaka keluarga besar seperti, abu leluhur, rumah peninggalan keluarga besar dan perhiasan-perhiasan turun temurun dari para pendahulu. Penerapan membagi harta warisan pada pewaris etnis Tionghoa adalah terhadap anak lakilaki, terutama anak laki-laki pertama, sedangkan

${ }^{17}$ Willy Yuberto Andrisma. (2007). "Pembagian Harta Waris Dalam Adat Tionghoa di Kecamatan Ilir Timur I Kota Palembang Provinsi Sumatra Selatan,” Tesis. Semarang: Program Studi Magister Kenotariatan Universitas Diponegoro, h. 60.

${ }^{18}$ Fuad and Ratrie. op.cit., h. 116. anak perempuan bukan merupakan ahli waris. Harta warisan akan dapat dibagikan pada para ahli waris selepas orangtua meninggal dunia, janda meninggal dunia atau menikah kembali. ${ }^{19}$

Adapun pada masyarakat Tionghoa di Banjarmasin status anak laki-laki dan anak perempuan sebagai ahli waris dari orangtuanya memiliki kelayakan yang sama, dengan pengertian bahwa hak yang sama antara anak perempuan dan laki-laki tidak berarti akan mendapat penjatahan yang sama, semua tergantung keputusan dari pewaris. Parental Discretion sangat kental dalam tradisi Tionghoa sehingga apapun keputusan orangtua harus ditaati oleh anak termasuk masalah pembagian warisan. Pewaris dalam hal ini orangtua memiliki kekuasaan penuh untuk memutuskan bagaimana cara membagi harta kepada para ahli warisnya. ${ }^{20}$

Pada zaman modern ini sangat sedikit etnis Tionghoa Banjarmasin yang masih kolot berpegang pada hukum adat, kalaupun ada biasanya mereka tetap memberikan sedikit harta kepada anak perempuan tetapi anak laki-laki pertama tetap mendapatkan porsi terbanyak dalam pembagian warisan. Hal ini dikarenakan posisi laki-laki dalam adat Tionghoa sebagai penerus marga (Xing/She) dan mereka ditinggalkan tanggung jawab tertentu dalam pemeliharaan sebagian benda pusaka keluarga yang dinilai berharga di dalam kehidupan masyarakat Tionghoa, seperti adanya abu leluhur atau abu dari orangtua yang telah wafat harus dipelihara dengan baik oleh anak laki-laki tertua. Suami atau istri yang ditinggalkan oleh pewaris diperhatikan dan dipelihara oleh ahli waris yakni anak laki-laki tertua. Atas instruksi dari adat adalah sedemikian, maka harta dengan porsi terbanyak diberikan kepada anak laki-laki tertua. ${ }^{21}$

Harta benda pusaka lainnya seperti rumah warisan kadang kala oleh masyarakat Tionghoa Banjarmasin diberikan kepada ahli waris perempuan. Meski terlihat rumah adalah harta yang besar, namun di dalam adat Tionghoa rumah warisan termasuk benda pusaka penting yang tabu untuk dijual.

\footnotetext{
${ }^{19}$ Melisa Ongkowijoyo. (2018). "Pembagian Harta Warisan Bagi Ahli Waris Keturunan Tionghoa.” Spirit Pro Patria. Vol. IV No. 2: 98-104.

${ }^{20}$ Wawancara dengan Dharmajaya Jiemy Limaatmaja. Tokoh Tionghoa Banjarmasin. Tgl. 15 Maret 2020.

${ }^{21}$ Wawancara dengan Chandra Zeng. Warga Banjarmasin Etnis Tionghoa. Tanggal 18 Maret 2020.
} 
Pembagiannya adalah asset lancar dan bisnis berjalan diberikan kepada anak laki-laki, sedangkan asset tidak lancar yang sewaktu-waktu bisa jadi berubah liabilitas (karena tidak bisa diuangkan) menjadi milik ahli waris perempuan. ${ }^{22}$

Meski begitu keluarga dengan kondisi financial yang tergolong menengah atau sederhana biasanya akan membagi sama rata harta peninggalan tanpa pembedaan antara anak laki-laki atau perempuan, adik atau kakak. ${ }^{23}$ Keluarga seperti ini mengikuti hukum sesuai Burgerlijk Wetboek Voor Indonesie (BW) yang mengatur seluruh anak laki-laki maupun anak perempuan yang lahir dari sebuah perkawinan akan memperoleh harta warisan yang sama rata. Di dalam mendapatkan warisan, ada dua cara yaitu: 1) secara abintestaat (ahli waris berdasarkan UndangUndang); 2) secara testamenter (ahli waris karena ditunjuk dalam surat wasiat atau testamen). Sebagian besar warga Tionghoa Banjarmasin memilih untuk menuliskan wasiat sebelum mereka meninggal dengan Surat (Akta) Keterangan Hak Waris yang dibuat oleh notaris sesuai dengan KUH Perdata. ${ }^{24}$ Namun hal ini justru jarang dilakukan oleh mereka yang masih memegang adat dengan ketat. Mereka cenderung menganggap surat wasiat adalah hal yang tabu dan yang mereka lakukan akhirnya membagikan warisan dengan cara mengumpulkan anak-anaknya satu per satu dan membagikan harta peninggalan pewaris tanpa ada dokumentasi apapun dari pewaris. ${ }^{25}$ Oleh karena itu sesuai dengan aturan Pengadilan Negeri yang berkaitan pengalihan hak atas tanah, menghibahkan, mewakafkan, menjual, membalik nama sebidang tanah dan rumah oleh ahli waris yang semula tercatat atas nama almarhum atau almahumah, mereka harus membuat Keterangan Ahli Waris yang dibuat oleh ahli waris sendiri, yang disaksikan oleh Lurah dan diketahui Camat dari Desa dan Kecamatan tempat tinggal almarhum. ${ }^{26}$

Adapun di dalam masyarakat Tionghoa di Kota Banjarmasin, warisan bukan sesuatu yang pasti didapatkan oleh ahli waris. Bisa jadi ahli waris tidak

\footnotetext{
${ }^{22}$ Wawancara dengan Prasetyo. Warga Banjarmasin Etnis Tionghoa. Tanggal 18 Maret 2020.

23 Wawancara dengan Like Novia Halim. Warga Banjarmasin Etnis Tionghoa. Tanggal 18 Maret 2020.

24 Wawancara dengan Dharmajaya Jiemy Limaatmaja.

25 Wawancara dengan Prasetyo.

${ }^{26}$ Benni. op.cit., h. 7.
}

mendapatkan apapun kecuali harta pusaka leluhur dan abu leluhur atau orangtua. Karena mereka ingin anak-anak mereka berhasil dengan kerja keras sendiri dan bukan dari peninggalan orangtua. Biasanya mereka yang memilih tidak memberikan kepada ahli waris akan mendonasikan seluruh asset mereka untuk mereka yang kurang mampu dan hanya menyisakan sedikit sesuai dengan Legitieme Portie ${ }^{27}$ saja. ${ }^{28}$

Masyarakat Tionghoa Banjarmasin yang telah memeluk agama Islam sekeluarga (tidak ada yang berbeda agama antara orangtua dan anak) lebih cenderung memakai aturan Islam ketimbang adat ataupun Kitab Undang-Undang Hukum Perdata (KUHP). Hal ini karena mereka mengakui bahwa Islam sudah sangat sempurna mengatur segala hal termasuk warisan dan rujukan yang mereka pakai adalah syariat Islam. ${ }^{29}$ Selain itu hal ini juga disebabkan adanya simpul budaya antara anggota masyarakat Tionghoa yang memeluk agama Islam dengan budaya Banjar Melayu yang sama-sama memiliki sistem kewarisan Patrilineal.

Berbeda dengan etnis Tionghoa beragama selain Islam, keluarga Tionghoa beragama Islam di Banjarmasin kebanyakan tidak melakukan pembagian berdasarkan parental discretion dimana jumlah bagian yang dibagikan kepada ahli waris adalah sesuai apa yang diberikan oleh pewaris atau tidak membagikan sama sekali. Mereka tidak bisa menentukan bagian karena dalam Islam bagian warisan telah ditetapkan oleh Allah sesuai dengan Al-Qur'an surah An-Nisa ayat 7 dan mengenai kebijaksanaan Allahlah yang benar dan bukan kebijaksanaan pewaris seperti dalam Al-Qur'an surah An-Nisa ayat 11.

Apabila dikemudian hari terjadi perselisihan terutama hal-hal yang berkaitan dengan penjatahan warisan, maka pada umumnya mereka akan berusaha menyelesaikannya sendiri secara kekeluargaan dengan cara musyawarah tertutup yang hanya terbatas dalam ruang lingkup keluarga inti saja. Sangat jarang sekali persengketaan mengenai pembagian harta waris dibawa sampai ke pengadilan karena masyarakat Tionghoa di Banjarmasin memandang hal

${ }^{27}$ Legitieme Portie adalah suatu bagian warisan tertentu yang harus diterima seorang ahli waris dari harta peninggalan yang tidak dapat diganggu gugat.

28 Wawancara dengan Chandra Zeng.

29 Wawancara dengan Hwang Ie Raharja Salim. Warga Banjarmasin Etnis Tionghoa. Tanggal 18 Maret 2020. 
tersebut menggambarkan sebuah aib bagi keluarga. Jikalau sampai ada perselisihan internal keluarga hanya karena perihal pembagian harta waris sampai ketahuan oleh masyarakat umum maka akan keluarga besar akan sangat malu dan merusak citra atau nama baik keluarga tersebut. ${ }^{30}$

\section{Kedudukan Hak Waris Anak Beragama Islam Dengan Orangtua Berbeda Agama Pada Masyarakat Tionghoa Banjarmasin}

Dalam konstruksi masyarakat perkotaan yang sering jelas terlihat adalah keberagaman dalam ciriciri sosial, psikologis, agama dan kepercayaan, adatistiadat, dan tingkah laku nya. Lingkungan sosialnya lebih didominasi oleh perbedaan kedudukan dan kontribusi di dalam sistem masyarakatnya. Di dalam konstruksi masyarakat plural juga lebih menghargai prestasi daripada garis keturunan. Dengan demikian, struktur masyarakat perkotaan sering mengalami persimpangan sosial, mobilitas sosial, dan dinamika sosial, sehingga bukanlah menjadi sesuatu yang mustahil ketika anak dan orangtua memiliki keyakinan agama yang berbeda. Hal sedemikian juga berlangsung pada etnis Tionghoa di Banjarmasin. ${ }^{31}$

Pembagian harta waris kepada ahli waris yang memeluk agama berbeda dengan pewaris adalah suatu problematika lain bagi etnis Tionghoa Banjarmasin. Hal ini dikarenakan yang menjadi warisan pada hukum adat Tionghoa bukan hanya asset berupa harta benda namun juga harta pusaka dan termasuk didalamnya abu leluhur dan abu orangtua pada anggota masyarakat adat Tionghoa yang masih memegang dengan erat tradisinya dan masih melakukan proses pembakaran jenazah. ${ }^{32}$

Hal ini tentu saja tidak dapat dilanjutkan kepada anak yang telah masuk agama Kristen Protestan atau agama Islam yang menganggap ritual adat Tionghoa tidak sejalan dengan aqidah mereka. Karena meski disebut ritual adat tetapi didalamnya ada ritus keagamaan yang menjadi bagian tradisi ini yaitu seperti pemujaan kepada leluhur dengan memberikan

\footnotetext{
${ }^{30}$ Wawancara dengan Prasetyo.

${ }^{31}$ Adon Nasrullah Jamaludin. (2017). Sosiologi Perkotaan: Memahami Masyarakat Kota dan Problematikanya. Bandung: CV Pustaka Setia, h. 77.

${ }^{32}$ Neng Emawati. (2018). "Hubungan Muslim Tionghoa Dengan Keluarganya Non Muslim Dalam Sistem Pembagian Waris (Studi Di Yayasan Haji Karim Oie)." Skripsi. Jakarta: Universitas Islam Negeri Syarif Hidayatullah Jakarta, h. 35.
}

(menyalakan) dupa dan menghidangkan makanan, serta perbuatan meminta kepada leluhur untuk mendapatkan berkat. ${ }^{33}$

Oleh sebab itu, kebanyakan masyarakat Tionghoa merestui anaknya menganut agama yang berbeda selama masih mau menjalankan tradisi. Sedangkan untuk memilih agama Kristen Protestan terlebih lagi memilih untuk masuk agama Islam, mereka akan berusaha melarang terlebih dahulu dan bahkan ada yang keras untuk tidak memberikan restu. Di Banjarmasin perpindahan agama ini kebanyakan terjadi karena pernikahan. Tionghoa Banjarmasin cenderung lebih longggar terhadap anak perempuan dibandingkan kepada anak laki-laki untuk hal menikah dengan suku lain dan agama lain. ${ }^{34}$

Parental Discretion dalam adat Tionghoa sangat kental sampai pada perkara pembagian warisan. Oleh karena itu semua masalah pembagian warisan terhadap anak yang berbeda keyakinan adalah sangat bergantung pada kebijaksanaan, keinginan dan restu orangtua. Bagi mereka yang memberikan restu dan masih menjaga hubungan baik dengan anak yang berbeda keyakinan, maka biasanya tetap memberikan hak waris kepada ahli warisnya. Sedangkan bagi mereka yang tidak direstui maka kemungkinan terbesar akan dicoret dari daftar ahli waris. ${ }^{35}$ Mereka yang tidak merestui anak pindah agama menjadi Islam maka akan membuat surat wasiat yang berisi siapa yang berhak mewarisi dan tidak memuat nama anak tersebut dari daftar ahli waris. ${ }^{36}$

Hal ini sejalan dengan pendapat jumhur ulama Islam mengenai perbedaan agama menjadi hijab (penghalang) dalam waris sebagaimana hadis yang diriwayatkan oleh Usamah bin Zaid. Oleh karena itu anak yang sudah beragama Islam biasanya tidak akan menuntut jika dihapus dari daftar ahli waris karena memahami konsekuensi syariah sebelum berpindah agama. ${ }^{37}$

Namun mereka yang menerima perbedaan keyakinan dan tetap ingin mewariskan harta kepada anaknya meski berbeda agama biasanya akan memakai hukum waris sesuai KUHP. Sebab

\footnotetext{
${ }^{33}$ Wawancara dengan Prasetyo.

34 Wawancara dengan Fenny. Warga Banjarmasin Etnis Tionghoa. Tanggal 15 Maret 2020.

35 Wawancara dengan Dharmajaya Jiemy Limaatmaja.

${ }^{36}$ Wawancara dengan Dharmajaya Jiemy Limaatjaya.

${ }^{37}$ Wawancara dengan Hwang Ie Raharja Salim.
} 
dalam hukum perdata tidak ada aturan pembatasan mewarisi beda agama. Pasal 838 KUHP menyatakan orang yang dianggap tidak patut menjadi pewaris adalah: pertama, mereka yang telah dihukum karena dipersalahkan telah membunuh, atau mencoba membunuh si yang meninggal; kedua, mereka yang dengan putusan hakim pernah dipersalahkan karena secara fitnah telah mengajukan pengajuan terhadap si yang meninggal, ialah suatu pengaduan telah melakukan suatu kejahatan yang terancam dengan hukuman penjara lima tahun lamanya atau hukuman yang lebih berat; ketiga, mereka yang dengan kekerasan atau perbuatan telah mencegahi yang meninggal untuk membuat atau mencabut surat wasiatnya; dan keempat, mereka yang telah menggelapkan, merusak, atau memalsukan surat wasiat si yang meninggal. ${ }^{38}$

Masyarakat Tionghoa yang beragama Islam biasanya jika diberikan oleh orangtuanya warisan, meskipun berbeda agama tetap menerimanya dan tidak menolak meskipun dalam Hukum Waris Islam memerintahkan apabila seorang ahli waris yang sudah beragama Islam maka ia tidak mewarisi kepada orang tuanya yang memiliki agama yang berbeda dengannya. ${ }^{39}$ Menjadi ahli waris dari orangtua yang tidak beragama Islam memang bertentangan dengan pendapat jumhur ulama, namun ada ulama yang berpendapat boleh mewarisi dari pewaris beragama selain Islam.

Seperti pendapat YusufAl-Qardhawi berdasarkan riwayat dari Umar, Mu'adz, dan Muawiyah yang terdapat dalam kitab Al-Mughni. Yusuf Al-Qardhawi menyebutkan bahwa mereka mempersilahkan ahli waris yang menganut agama Islam mewarisi dari pewaris yang berbeda agama dengannya, akan tetapi tidak berlaku sebaliknya. Hal ini dapat dibenarkan karena umat Islam diperkenankan atau dibolehkan untuk menikah dengan perempuan dari kalangan orang-orang kafir, dan mereka yang tidak beragama Islam tidak diperbolehkan menikah dengan perempuan yang beragama Islam, sebagaimana AlQur'an Surah Al-Maidah ayat (5). ${ }^{40}$

\footnotetext{
${ }^{38}$ Alvi Lailla Choyr. (2019). "Studi Komparatif Hak Waris Anak Beda Agama Menurut Hukum Islam dan Hukum Perdata." Skripsi. Ponorogo: IAIN Ponorogo, h. 64.

${ }^{39}$ Wawancara dengan Fenny.

${ }^{40}$ Rizkal. (2016). "Pemberian Hak Waris Dalam Hukum Islam Kepada Non-Muslim Berdasarkan Wasiat Wajibah.” Yudisial. Vol. 9 No. 16 Agustus: 173-193.
}

\section{PENUTUP}

\section{Kesimpulan}

Implementasi hukum waris yang diterapkan oleh masyarakat Tionghoa Banjarmasin berubah dari sistem hukum adat yang semula hanya memberikan hak waris kepada anak laki-laki terutama anak tertua, menjadi seperti yang ada pada hukum waris Perdata Barat dimana perempuan juga mendapatkan hak waris. Cara ini juga masih menimbulkan ketidakadilan dalam pembagian harta waris yang tidak sama rata karena jumlah harta waris masih lebih besar pada bagian anak laki-laki. Pembagiannya sangat dipengaruhi oleh kebijaksanaan orangtua (pewaris) untuk memilih berapa bagian dan siapa saja yang mendapatkan hak waris dan berkaitan dengan tradisi bahwa anak laki-laki bertanggungjawab kepada keluarga besar.

Kedudukan hak waris anak beragama Islam di keluarga Tionghoa Banjarmasin yang beragama Islam juga maka diterapkan sistem waris sesuai dengan hukum Islam. Di sisi lain, keluarga yang memegang tradisi dan kolot cenderung memilih menghapus hak ahli waris jika berbeda keyakinan dengan orangtua (pewaris).

\section{Rekomendasi}

Apabila terjadi konflik hukum waris, keluarga dapat menempuh cara litigasi sesuai pilihan hukum yang mereka ambil maupun cara non-litigasi. Pengadilan agama bagi yang menerapkan hukum Islam dan Pengadilan negeri bagi yang menerapkan hukum Perdata. Bagi keluarga Tionghoa di Banjarmasin yang masih berpegang teguh pada ajaran adat Tionghoa yaitu tidak boleh membawa sengketa perdata ke pengadilan karena dianggap tabu dan memalukan nama besar keluarga maka penyelesaian secara non litigasi secara kekeluargaan dapat lebih diutamakan.

\section{DAFTAR PUSTAKA}

\section{Peraturan Perundang-undangan:}

Kitab Undang-Undang Hukum Perdata.

Undang-Undang Dasar 1945, Hasil Amandemen KeEmpat, 10 Agustus 2002.

Undang-Undang No. 1 Tahun 1974 tentang Perkawinan. 


\section{Buku:}

Adon Nasrullah Jamaludin. (2017). Sosiologi Perkotaan: Memahami Masyarakat Kota dan Problematikanya. Bandung: CV Pustaka Setia.

Muhammad bin Ismail Al Bukhari. Shahih Bukhari (Beirut: Dar Ibn Katsir, n.d.). Hadis no. 42824283, 6267; Muslim bin al Hajjaj bin Muslim bin Kausyaz al-Qusyairi An-Naisaburi, Shahih Muslim, ed. Dede Ishaq Munawar (Jakarta: Pustaka As-Sunnah, 2010). Hadis No. 1614; Abu Daud Sulaiman bin Al-Asy'atsi Al-Sijistaanii, Sunan Abu Daud (Makkah: International Ideas Home, 1999). Hadis No. 2909; Muhammad bin Isa At-Tirmidzi, Sunan Tirmidzi (Riyadh: Maktabatu Al Ma'arif, n.d.). Hadis No. 2107.

Suteki and Galang Taufani. (2018). Metodologi Penelitian Hukum (Filsafat, Teori dan Praktik). Depok: Raja Grafindo Persada.

\section{Jurnal:}

Beatrix Benni. "Pewarisan Pada Etnis Tionghoa Dalam Pluralitas Hukum Waris Di Indonesia." Masalah-Masalah Hukum. Vol. 44 No. 1 Januari 2015: 1-10.

Fokky Fuad and Ratrie. "Kedudukan dan Hak Waris Bagi Perempuan Dalam Budaya Hukum Confucius." Lex Jurnalica. Vol. 4 No. 3 Agustus 2007: 116-131.

Isti Sulistyorini. "Pergeseran Hukum Pewarisan Masyarakat Tionghoa Di Kota Pekalongan." Jurisprudence. Vo. 1 No. 2 Juli 2013: 367-376.

Kurnia Widiastuti and Anna Oktaviana. (2018). "Bentuk Dan Makna Rumah Tinggal Etnis Tionghoa Di Banjarmasin." Info Teknik. Vol. 16 No. 2. https://doi.org/10.1017/ CBO9781107415324.004, h. 1689-1699.

Melisa Ongkowijoyo. (2018). "Pembagian Harta Warisan Bagi Ahli Waris Keturunan Tionghoa." Spirit Pro Patria. Vol. IV No. 2: 98-104.

Rizkal. (2016). "Pemberian Hak Waris Dalam Hukum Islam Kepada Non-Muslim Berdasarkan Wasiat Wajibah." Yudisial. Vol. 9 No. 16 Agustus: 173193.

\section{Skripsi/Tesis:}

Alvi Lailla Choyr. (2019). "Studi Komparatif Hak Waris Anak Beda Agama Menurut Hukum Islam Dan Hukum Perdata." Skripsi. Ponorogo: IAIN Ponorogo.

Muhammad Sidik. (2018). Hubungan Antar Penganut Agama Dalam Keluarga (Studi Kasus Etnis Tionghoa Di Banjarmasin). Skripsi. Banjarmasin: Universitas Islam Negeri Antasari. Neng Emawati. (2018). "Hubungan Muslim Tionghoa Dengan Keluarganya Non Muslim Dalam Sistem Pembagian Waris (Studi Di Yayasan Haji Karim Oie)." Skripsi. Jakarta: Universitas Islam Negeri Syarif Hidayatullah Jakarta.

Willy Yuberto Andrisma. (2007). "Pembagian Harta Waris Dalam Adat Tionghoa di Kecamatan Ilir Timur I Kota Palembang Provinsi Sumatra Selatan," Tesis. Semarang: Program Studi Magister Kenotariatan Universitas Diponegoro.

\section{Website:}

Badan Perencanaan Pembangunan Daerah Kota Banjarmasin dan Badan Pusat Statistik Kota Banjarmasin. (2013). "Profil dan Analisis Hasil Sensus Penduduk 2010 dan Proyeksi Penduduk 2010-2020 Kota Banjarmasin”. https://banjarmasinkota.bps.go.id/subject/12/ kependudukan.html\#subjekViewTab3.

Badan Pusat Statistik Kota Banjarmasin. (2019). "Kota Banjarmasin Dalam Angka". https://banjarmasinkota.bps.go.id/ publication/2019/08/16/aa133421b542480 $4385 \mathrm{f0b58/kota-banjarmasin-dalam-}$ angka-2019.html.

Roedy Haryo Widjono AMZ. (2019). "Jejak Migrasi Etnis Tionghoa Di Kalimantan." https://www. akurasi.id/jejak-migrasi-etnis-tionghoa-dikalimantan/. 